\title{
ANÁLISE DE DIFERENTES TIPOS DE CIMENTO PORTLAND EM RELAÇ̃̃O A TAXA DE FISSURAÇÃO PROVENIENTE DO MECANISMO DE RETRAÇÃO.”
}

\author{
MARÇULA, STEPHANIE CUCOLO MARÇULA, STEPHANIE \\ Estudante \\ Centro Universitário Metrocamp/ Wyden \\ São Paulo; Brasil São Paulo; Brasil \\ stephanie.cucolo@gmail.com
}

\author{
PEREIRA, JONATHA ROBERTO PEREIRA, JONATHA \\ Professor \\ Centro Universitário Metrocamp / Wyden \\ São Paulo; Brasil São Paulo; Brasil \\ jonatha.pereira@unimetrocamp.edu.br
}

\section{RESUMO}

O cimento Portland está presente em vários tipos de construções. Associado a outros materiais é capaz de adquirir características que fazem do concreto o segundo produto mais consumido no mundo. A fissuração por retração plástica é uma interação complexa que tem origem a começar pela hidratação da pasta de cimento. Presume-se que a perda de água através dos vasos capilares deste composto está diretamente associada às condições de secagem (temperatura e umidade) que resultam em microfissuras na zona de transição e consequentemente deformação do material ao longo dos anos. O presente artigo tem como objetivo comparar os diferentes tipos de cimento Portland (CP Branco, CP II, CP III, CP IV, CPV), através de ensaios de retração restringida baseada na norma americana ASTM C1579 "Standart Test Method for Evaluing Plastic Shrinkage Cracking of Restrained Fiber Reinforced Concrete (Using a Steel Form Insert). Utilizou-se quinze (15) traços, relacionando o fator água/cimento 0,30,045 e 0,60 com as diferentes qualidades de cimento Portland. Após ensaios foi possível observar que os maiores índices de fissuras (quantidade, tamanho e profundidade) deu-se através de compostos pozolânico e de alta resistência (CP IV e CPV) e com fatores a/c maiores.

Palavras-chave: retração, fissuras, cimento Portland.

\section{ABSTRACT}

Portland cement is present in many types of buildings. Associated with other materials it is able to acquire characteristics that make concrete the second most consumed product in the world. Plastic shrinkage cracking is a complex interaction that originates from hydrated cement paste. It is assumed that the loss of water through the capillaries of this compound is directly associated with the drying conditions (temperature and humidity) that result in microcracks in the transition zone and consequently material deformation over the years. This paper aims to evaluate the influence of the addition of different cementitious compounds on the production of different types of cement (CP White, CP II, CP III, CP IV, CPV) through restricted shrinkage tests based on the American standard ASTM C1579. Standart Test Method for Evaluating Plastic Shrinkage Cracking of Restrained Fiber Reinforced Concrete (Using a Steel Form Insert). Fifteen (15) traits were used, relating the water / cement factor $0.30,045$ and 0.60 with the different types of cement. After tests it was possible to observe that the highest indices of cracks, both in quantity, size and depth occurred through pozzolanic and high strength compounds (CP IV and CPV) and with higher a / $\mathrm{c}$ factors.

Keywords: skincracking, fissures, cement Portland. 